(C) Elsevier/INRA

Short communication

\title{
Localization of leucocyte interferon gene in the q2.5 region of pig chromosome1 by in situ hybridization
}

\author{
M. Yerle and J. Gellin
}

Institut National de la Recherche Agronomique, centre de recherches de Toulouse, laboratoire de génétique cellulaire, BP27, 31326 Castanet-Tolosan Cedex, France

(received 11 April 1989, accepted 5 May 1989)

Summary - Using in situ hybridization and the random primer method to label the probe, we reduced the region of localization of leukocyte interferon gene on pig chromosome 1 from (q2.2 - q2.7) to $\mathrm{q} 2.5$.

pig - leukocyte interferon - in situ hybridization

Résumé - Localisation précise, par hybridation in situ, d'un gène interféron $\alpha$ sur le chromosome 1 du porc. L'utilisation en hybridation in situ de la sonde correspondant au gène de l'interféron $\alpha$, marquée par le système d'amorces oligonucléotidiques, a permis de réduire la zone de localisation de ce gène sur le chromosome 1 du porc de la région q2.2 $\rightarrow$ q2.7 à la région q2.5.

porc - interferon $\alpha$-hybridation in situ

\section{INTRODUCTION}

In 1986, we mapped the leukocyte interferon gene on pig chromosome 1 by in situ hybridization (Yerle et al. 1986). The labeled region (q2.2 - q2.7) appeared to be large, considering that the probe used, contained only one alpha interferon gene. We thought that the probe could hybridize with the different alpha interferon genes that were supposed to present $80-95 \%$ homologies in nucleotide sequence, as in man and mouse. Nevertheless, after changing the labeling system of the probe, we increased the precision of the localization as we reduced it to one band: q2.5.

\section{MATERIALS AND METHODS}

The metaphase spreads were obtained from peripheral blood lymphocyte cultures, established from normal male pigs. The metaphases were G banded (GTG banding technique) before hybridization and the best ones were photographed. The probe was a recombinant plasmid pUC8 containing a fragment of $2700 \mathrm{bp}$ of genomic pig DNA, including an entire alpha interferon gene (Lefevre and Labonnardière, 
1986). The probe was labeled by the random primer method (Feinberg and Vogelstein, 1983), modified for tritium labeling. The specific activity obtained equaled $10^{8} \mathrm{dpm} / \mu \mathrm{mg}$. Appropriate amount of ${ }^{3} \mathrm{H}$-labeled probe was precipited by adding ethanol in the presence of a 1,000-fold excess of sonicated salmon sperm DNA. The precipitate was diluted in the following solution: $50 \%$ ionized formamide; $10 \%$ dextran sulfate; and $1 / 5$ volume of SCCP $(0.2 \mathrm{M}$ sodium phosphate, $\mathrm{pH} 6.8 ; 1.2 \mathrm{M}$ sodium chloride; and $0.15 \mathrm{M}$ trisodium citrate).

The concentration of the probe DNA was $0.5 \mu \mathrm{g} / \mathrm{ml}$. The technique used for in situ.hybridization has been described elswhere (Gellin et al., 1985), and we added only some modifications concerning the washings after hybridization: the slides were first rinsed in $2 \times \mathrm{SSC}$ at room temperature, and in $50 \%$ formamide and $2 \times \mathrm{SSC}$ at $37^{\circ} \mathrm{C}$ for $1 \mathrm{~h}$, then carefully washed in $2 \times \mathrm{SSC}$. Labeling was revealed by autoradiography. The slides were restained with Giemsa, and the metaphases compared with their appearance before hybridization, to locate the silver grains and identify the chromosomes. The chromosomes were classified according to the G-band pattern, defined by the Committee for the standardized karyotype of the Domestic Pig (1988).

\section{RESULTS AND DISCUSSION}

A total of 69 well-banded chromosome spreads were scored. Among 579 grains counted on the chromosomes (Fig. 1), $500(86 \%)$ were observed on chromosome 1 and out of the 500 grains counted on this chromosome, $330(66 \%)$ were in the region q2.5 (Fig. 2). Among the total number of metaphases scored, $87 \%$ showed both chromosomes 1 labeled in this region. One of them is presented in Figure 3.

If we compare these results with those obtained in 1986 (Figs. 2a and 2b), we have improved the technique; the percentage of grains on pig chromosome 1 is increased from $31 \%$ to $86 \%$ and the region is reduced from (q2.2 - q2.7) to one band $\mathrm{q} 2.5$. The number of grains pointed in this region is so high, that we could have reduced the number of spreads scored to one third and still maintain a significant signal. In the first experiments, only $5 \%$ of the metaphases showed both chromosomes 1 labeled. Here, this percentage reaches $87 \%$. One possible explanation could be that, by oligo-labeling with ${ }^{3} \mathrm{H}$-nucleotides, we obtain a specific activity 5 -10 times higher than by nick-translation. Furthermore, in this technique, DNAse is not used as it is in the nick-translation method thereby, permitting more reproducible results. The high specific activity could partly explain the efficiency of in situ hybridization. This observation confirms the one given by Lin et al. 1985 .

We have also modified the washings after hybridization. They are less stringent and, in consequence, we have retained signal possibly lost in the first experiments (Yerle et al., 1986). 


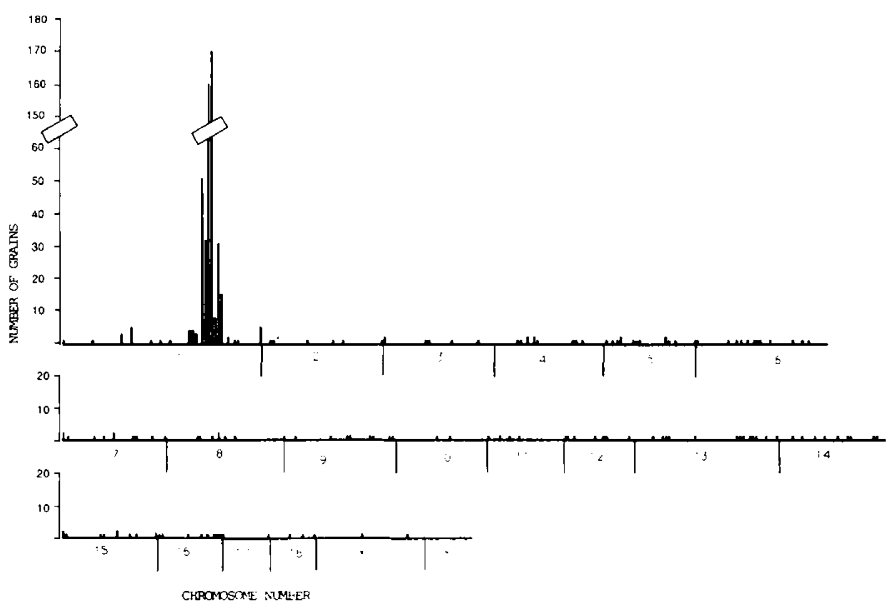

Fig. 1. Histogram showing the distribution of silver grains from 69 G-banded metaphase spreads. A remarkably high concentration of grains was located on the chromosome region $1 \mathrm{q} 2.5$, with very few grains distributed on other chromosome regions.
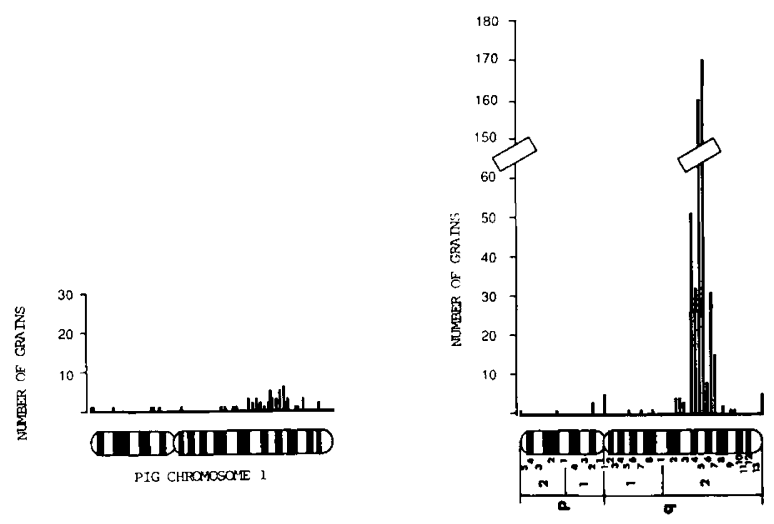

Fig. 2. Distribution of silver grains on chromosome 1 .

a. Hybridization of a nick-translated $\alpha$ interferon gene probe (106 metaphases scored; Yerle et al., 1986)

b. Hybridization of the same probe labeled by the random primer method (69 metaphases scored, this paper).

\section{CONCLUSION}

The possibility to obtain such acute regional assignment, combined with the use of high-resolution chromosome spreads, will be useful in several fields:

- localization of unique sequences,

- increasing the precision of gene localization on chromosomes (Lin et al., 1985),

- orientation of close genes (Morton et al., 1984), 


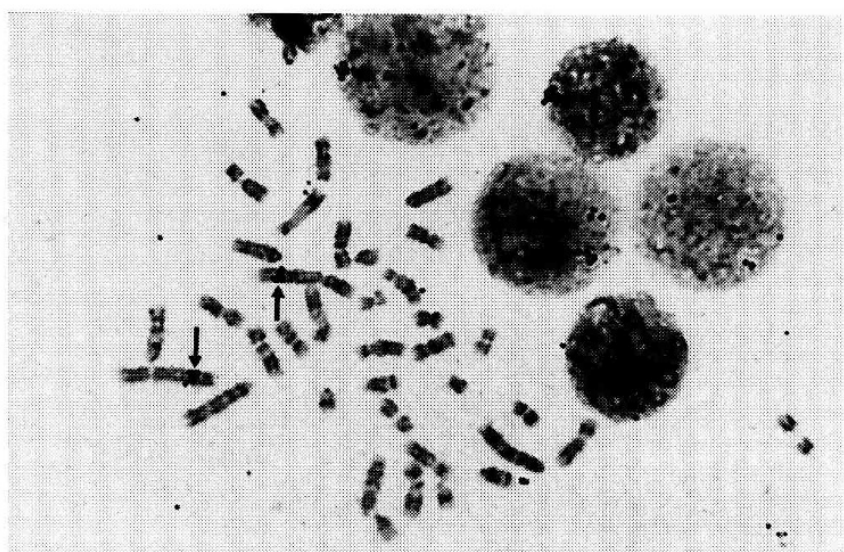

Fig. 3. A representative metaphase spread, hybridized with a ${ }^{3} \mathrm{H}$ labeled $\alpha$-interferon gene probe showing on both chromosomes 1 silver grains on region q2.5 (indicated by arrows).

- bridging the gap between the physical and the genetic maps, by the assignment of genes close enough to be considered as genetically linked.

\section{REFERENCES}

Committee for the standardized karyotype of the Domestic Pig (1988) Standard karyotype of the domestic pig. Hereditas 109(2) 151-158

Feinberg A.P. \& Vogelstein B. (1983) A technique for radiolabeling DNA restriction endonuclease fragments to high specific activity. Anal. Biochem. 132, 6-13

Gellin J., Echard G., Yerle M., Dalens M., Chevalet C. \& Gillois M. (1985) Localization of the $\alpha$ and $\beta$ casein genes to the q2.4 region of chromosome 12 in the rabbit (Oryctolagus cuniculus L.) by in situ hybridization. Cytogenet. Cell Genet. 39, 220-223

Lefevre F. \& Labonnardière C. (1986) Molecular cloning and sequencing of a gene incoding biologically active porcine interferon alpha. J. Interferon Res. 6, 349-360 Lin C.C., Draper P.N. \& De Braekeleer M. (1985) High-resolution chromosomal localization of the $\beta$-gene of the human $\beta$-globin gene complex by in situ hybridization. Cytogenet. Cell Genet. 39, 269-274

Morton C.C., Kirsch I.R., Nance W.E., Evans G.A., Korman A.J. \& Strominger J.L. (1984) Orientation of loci within the human major histocompatibility complex by chromosomal in situ hybridization. Proc. Natl. Acad. Sci. 81, 2816-2820 Yerle M., Gellin J., Echard G., Lefevre F. \& Gillois M. (1986) Chromosomal localization of leukocyte interferon gene in the pig (Sus scrofa domestica L.) by in situ hybridization. Cytogenet. Cell Genet. 42, 129-132 